\title{
Mefluidide effect on weeping lovegrass heading, forage yield, and quality
}

\author{
LARRY M. WHITE
}

\section{Abstract}

Weeping lovegrass [Eragrostis curvula (Schrad.) Nees.] provides high quality forage during May, but growth of floral stems causes a rapid decline in forage quality. The study objective was to determine which combination of date and rate of mefluidide [N(2,4-dimethy]-5-\{[(trifluoro methyl) sulfonyl \}amino\}phenyl)acetamide], a growth regulator, would effectively decrease number of foral stems and thus maintain higher forage quality. Mefluidide $(0.00,0.28,0.56$, and $0.84 \mathrm{~kg} / \mathrm{ha})$ was applied to lovegrass on 1 of 3 , 2,5 , and 5 dates in 1984, 1985, 1986, and 1987, respectively. Lovegrass was grown on a Pratt fine sandy loam (Thermic Psammentic Haplustalf) soil near Woodward, Okla. Factorial combinations of treatments were rerandomized within the study area each year. Plots $(1.8$ by $5 \mathrm{~m}$ ) were replicated 6 times in a randomized complete block design. Forage was harvested in mid June to early July with a sickle bar at seed ripe. Mefluidide reduced the number of floral stems only when applied 1 week after floral primordium initiation. Mefluidide application 1 week earlier or later had little effect on number of floral stems, forage yield, in vitro dry matter digestibility (IVDMD), or crude protein (CP). Application of 0.56 $\mathrm{kg} / \mathrm{ha}$ of mefluidide 1 week after floral primordium initiation decreased number of floral stems 58 to $93 \%$, decreased forage yield 14 to $23 \%$, increased percent leaves 4 to 32 percentage units, and had little effect on leaf yield. It increased whole-plant IVDMD 1.6 to 2.8 and $C P$ 0.2 to 1.6 percentage units depending upon year. Generally, mefluidide had little effect on leaf or stem IVDMD or CP that averaged 49 and $7.5 \%$ for leaves and 39 and $5.1 \%$ for stems, respectively. The effective 'window' for mefluidide application is probably too short for practical use by farmers or ranchers.

Key Words: Eragrastis curvula, crude protein, in vitro dry matter digestibility, growth regulator, phenology, foral development

Weeping lovegrass [Eragrostis curvula (Schrad.) Nees.] provides high quality forage during May, but growth of floral stems causes a rapid decline in forage quality. Voigt et al. (1981) found that in vitro dry matter digestibility (IVDMD) of lovegrass decreased 0.5 percentage units per day from jointing until anthesis. Twidell et al. (1988) found that changes in proportion and composition of the stem and sheath fractions of switchgrass (Panicum virgatum $\mathrm{L}$.) were major factors causing a decline in herbage quality with maturation. In a literature review, Hacker and Minson (1981) noted that digestibility of stems declined twice as fast as that of leaves. Even if IVDMD of leaves and stems were similar, this does not make them equal in nutritional quality. Minson (1972) and Laredo and Minson (1973) found that intake of leaves by sheep was $59 \%$ greater than that of stems even when in vivo digestibility of both was similar. If the number of floral stems could be reduced, it should improve forage quality and animal weight gains.

Application of mefluidide[N-(2,4-dimethyl-5-\{[(trifluoromethyl)sulfonyl]amino\}phenyl)acetamide], a growth regulator, has effectively reduced floral stems of several grasses. Mefluidide application at or near flora primordium initiation of crested wheatgrass [Agropyron desertorum (Fisch.) Schult.] decreased forage yield 20

\footnotetext{
Author is range scientist, USDA-ARS, Southern Plains Range Research Station, 2000-18th St., Woodward, Okla. 73801 .

This article is a contribution from USDA-ARS

Manuscript accepted 24 March 1991.
}

to $60 \%$ but increased in vitro organic matter digestibility 2 to 5 percentage units (Haferkamp et al. 1987, McCaughey and Cohen 1989, White 1989). Mefluidide application to smooth brome (Bromus inermis Leyss.) decreased forage yield $60 \%$ during summer (Baron et al. 1989, Sheaffer and Marten 1986, Wimer et al. 1986) but increased animal weight gains/ha (Wimer et al. 1986). Mefluidide decreased forage yield of bermudagrass [ Cynodon dactylon (L.) Pers. var. dactylon] (DeRamus and Bagley 1984) and tall fescue (Festuca arundinacea Schreb.) (Robb et al. 1983, Lomas and Moyer 1985) yet increased season-long animal weight gains.

The study objective was to determine the effects of mefluidide application dates and rates on number of floral stems, forage yield, leaf percentage, IVDMD, and crude protein (CP) of leaves and stems of weeping lovegrass.

\section{Materials and Methods}

The study was conducted at Woodward, Okla., during 1984, 1985,1986 , and 1987 on a stand of common weeping lovegrass seeded in 91-cm rows during the early 1950 s. Plants expanded until only $30 \mathrm{~cm}$ remained between rows. The site was harvested for hay for several years prior to the study and not fertilized. Site elevation is $600 \mathrm{~m}$ and the soil is a Pratt fine sandy loam (Thermic Psammentic Haplustalf). Previous years' aftermath was burned in March just after lovegrass started growth (Table 1). The site was then

Table 1. Dates of burning, nitrogen fertilization, stems counted, forage harvest, and dates weeping lovegrass reached various growth stages in 1984 through 1987 at Woodward, Okla.

\begin{tabular}{|c|c|c|c|c|}
\hline & \multicolumn{4}{|c|}{ Year } \\
\hline & 1984 & 1985 & 1986 & 1987 \\
\hline $\begin{array}{l}\text { Burned } \\
\text { Fertilized } \\
\text { Stem count } \\
\text { Harvested }\end{array}$ & $\begin{array}{l}30 \text { Mar. } \\
18 \text { Apr. } \\
5 \text { July } \\
5 \text { July }\end{array}$ & $\begin{array}{l}29 \text { Mar. } \\
5 \text { Apr. } \\
24 \text { June } \\
25 \text { June }\end{array}$ & $\begin{array}{l}10 \text { Mar. } \\
18 \text { Mar. } \\
10 \text { June } \\
18 \text { June }\end{array}$ & $\begin{array}{l}6 \text { Mar. } \\
2 \text { Apr. } \\
15 \text { June } \\
22 \text { June }\end{array}$ \\
\hline $\begin{array}{l}\text { Pre-primordium } \\
\text { Pre-primordium } \\
\text { Primordium, 1-2mm } \\
\text { Primordium, } 1-2 \mathrm{~cm} \\
\text { Headed }<1 \% \\
\text { Headed } 10-50 \%\end{array}$ & $\begin{array}{l}15 \mathrm{May} \\
22 \mathrm{May} \\
29 \mathrm{May}\end{array}$ & $\begin{array}{l}30 \text { Apr. } \\
8 \text { May }\end{array}$ & $\begin{array}{l}3 \text { Apr. } \\
9 \text { Apr. } \\
16 \text { Apr. } \\
24 \text { Apr. } \\
30 \text { Apr. }\end{array}$ & $\begin{array}{r}23 \text { Apr. } \\
29 \text { Apr. } \\
7 \text { May } \\
13 \text { May } \\
21 \text { May }\end{array}$ \\
\hline
\end{tabular}

fertilized with ammonium nitrate at $114 \mathrm{~kg} \mathrm{~N} /$ ha the first 2 years and $68 \mathrm{~kg} \mathrm{~N} /$ ha the last 2 years.

Average annual precipitation is $598 \mathrm{~mm}$ with $24 \%$ received from September through November, $10 \%$ from December through February, 32\% from March through May, and 34\% from June through August (Table 2). January and July long-term mean temperatures are 2 and $28^{\circ} \mathrm{C}$, respectively, and the average frost-free period is 177 days.

Mefluidide $(0.00,0.28,0.56$, and $0.84 \mathrm{~kg} /$ ha active ingredient) was applied to lovegrass on 1 of 3,2, 5, and 5 dates in 1984, 1985, 1986 , and 1987, respectively. Factorial combinations of treatments were rerandomized within the study area each year. Plots $(1.8$ by 5 $\mathrm{m}, 1 \mathrm{~m}$ border at end of each plot) were replicated 6 times in a randomized complete block design. The first 2 years, mefluidide 
Table 2. Precipitation received a study site near Woodward, Okla. from 1983 through 1987.

\begin{tabular}{lcccc}
\hline & \multicolumn{4}{c}{ Season } \\
\cline { 2 - 5 } Years & Sep.-Nov. & Dec.-Feb. & Mar.-May & June-Aug. \\
\hline & 197 & 32 & 179 & 117 \\
$1983-4$ & 138 & 160 & 227 & 335 \\
$1984-5$ & 311 & 21 & 127 & 311 \\
$1985-6$ & 224 & 101 & $\frac{336}{193}$ & $\frac{156}{202}$ \\
$1986-7$ & 142 & 61 & 193 & 202 \\
Normal & $\underline{14}$ & &
\end{tabular}

was first applied 1 week after lovegrass initiated the first floral primordium (Table 1) as determined by weekly examination of about 20 fall-initiated tillers from 4 to 5 nearby plants. The last 2 years, mefluidide was first applied 3 and 2 weeks before most floral primordia were initiated (Table 1). Mefluidide was applied in 150 and $200 \mathrm{~L} /$ ha of water in the first 2 and last 2 years, respectively. Mefluidide was applied at $3.2 \mathrm{~km} / \mathrm{hr}$ using 3 flat-fan nozzles (80015) mounted on a bicycle sprayer. The sprayer was pressurized with $\mathrm{CO}_{2}$ at $138 \mathrm{kPa}$ the first 2 years and at $207 \mathrm{kPa}$ the last 2 years.

Floral stems were counted the first year in a 0.86 by $5.0 \mathrm{~m}$ quadrat and the next 3 years in 3 quadrats $(0.3$ by $0.6 \mathrm{~m}$ ) within each plot during early seed dissemination (Table 1). Forage was harvested with a sickle bar from a 0.86 by $5.0-\mathrm{m}$ area the first 2 years and from a 1.25 by $5.0-\mathrm{m}$ area the last 2 years. The harvest area was centered within each plot. Forage was harvested to a $6-\mathrm{cm}$ stubble height all years. Forage from the remainder of the plot was removed a few days later. A 300 to $400-\mathrm{g}$ subsample (wet) of plant material was oven dried about $48 \mathrm{hr}$ at $60^{\circ} \mathrm{C}$ to constant weight. Subsamples from the first application date were hand separated into leaf and stem fractions the first year and from all application dates the next 3 years. The leaf fraction included both leaf blades and leaf sheaths while the stem fraction included only stems. Inflorescences were removed from the sample. Leaf percentage was calculated as percentage leaves made of the leaf plus stem dry matter yield. Leaf and stem fractions were ground to pass a 1-mm screen before analyses. The IVDMD was determined by a modification of the Tilley and Terry two-stage method where the nutrient buffer solution was supplemented with urea (White et al. 1981). Rumen fluid was obtained from steers fed $3.5 \mathrm{~kg}$ of alfalfa ( Medicago sativa L.), $0.9 \mathrm{~kg}$ of $41 \%$ protein cottonseed (Gossypium hirsutum L.) cake daily, and free choice weeping lovegrass hay. Nitrogen concentration was determined by semimicro-Kjeldahl method (Bremner and Breitenbeck 1983) and results multiplied by 6.25 to estimate CP.

Maximum and minimum air temperatures and precipitation was measured daily at the site in a standard weather station. Degree days [accumulated daily mean air temperature above $5^{\circ} \mathrm{C}$ threshold] accumulated from the first of February through the end of May were calculated.

Data were analyzed with a 3 date by 4 rate (first year), 2 by 4 (second year), and a 5 by 4 (third and fourth year) factorial analysis of variance for a randomized complete block design. Orthogonal polynomials were used to partition the date and rate treatment sum of squares into linear, quadratic, cubic, and quartic (date only last 2 years) components. The interaction sum of squares was partitioned into all possible combinations; e.g., date linear by rate cubic, and significance of each interaction was determined with an $F$ test (Cochran and Cox 1957). The procedure by White (1990) was used to determine which significant interactions identified by the analysis of variance $F$ test were used to plot 1984 and 1985 data. The equations used to plot the effects of mefluidide application date (weeks) and rates ( $\mathrm{kg} / \mathrm{ha}$ ) on floral stems, forage yield, whole-
Table 3. Regression equations for effects of mefluidide application dates (D) and rates (R) on floral stems, forage yield, whole-plant IVDMD and CP of weeping lovegrass during 1984 and 1985 near Woodward, Okla.

Equations

1984

Floral stems (no. $\left./ \mathrm{m}^{2}\right)=528-37.5 \mathrm{D}+4.65 \mathrm{D}^{2}-1372 \mathrm{R}-1028 \mathrm{DR}-186 \mathrm{D}^{2} \mathrm{R}$

Forage yield $(\mathrm{kg} / \mathrm{ha})=6012-604 \mathrm{D}-100 \mathrm{D}^{2}-6421 \mathrm{R}+5657 \mathrm{DR}-1132 \mathrm{D}^{2}$

IVDMD $(\%)=42.2-0.460 D+0.240 D^{2}+19.1 R-16.7 D R+3.44 D^{2} R$

$\mathrm{CP}(\%)=5.65-0.0700 \mathrm{D}+0.0500 \mathrm{D}^{2}+7.50 \mathrm{R}-5.78 \mathrm{DR}+1.07 \mathrm{D}^{2} \mathrm{R}$

1985

Floral stems $\left(\right.$ no. $\left./ \mathrm{m}^{2}\right)=402+82.2 \mathrm{D}-1728 \mathrm{R}+862 \mathrm{R}^{2}+442 \mathrm{DR}$

Forage yield $(\mathrm{kg} / \mathrm{ha})=5034+433 \mathrm{D}-3486 \mathrm{R}+2551 \mathrm{R}^{2}+7428 \mathrm{DR}$

IVDMD $(\%)=46.0-1.68 D+6.60 R-4.62 R^{2}-1.18 D R$

$C P(\%)=6.56-0.380 D+3.62 R-1.59 R^{2}-0.643 D R$

plant IVDMD and CP are shown in Table 3. The 3-dimensional surfaces of the 1986 and 1987 data were fitted with a bivariate spline and plotted with a SAS/GRAPH (SAS 1988). Polynomial equations even to the 4 th degree were not used to plot the 1986 and 1987 data because they plotted the surface widely over or under the expected surface between dates. All treatment differences reported are significant at the $P \leq 0.05$ probability level unless otherwise stated.

\section{Results and Discussion}

\section{Growth Conditions}

Colder than normal winter and spring temperatures delayed plant development about 2 weeks during 1984 (Table 1). Second and third year temperatures and plant development were near normal. The first crop year, forage yield $(5,400 \mathrm{~kg} / \mathrm{ha})$ on check plots was near normal while fall, winter, and spring precipitation was 139,52 , and $93 \%$ of normal (Table 2$)$. Forage yield $(5,800$ $\mathrm{kg} / \mathrm{ha}$ ) the second crop year was again near normal while fall and spring precipitation was near normal but winter precipitation was more than double normal. The third crop year, twice normal fall precipitation followed by one-third and two-thirds normal winter and spring precipitation caused severe plant wilting during April therefore, the site was sprinkled with $100 \mathrm{~mm}$ of water on 21 April and forage yield $(7,700 \mathrm{~kg} / \mathrm{ha})$ was above normal. Fall, winter, and spring precipitation the fourth crop year was 158,165 , and $174 \%$ of normal, yet lovegrass produced only $3,200 \mathrm{~kg} / \mathrm{ha}$ of forage on check plots probably because of a large decrease in number of floral stems compared to the first 2 years and application of only 68 $\mathrm{kg} \mathrm{N} /$ ha the current and previous year.

\section{Floral Stems}

Application of mefluidide was effective in reducing the number of lovegrass floral stems only when applied when the floral primordium was 1 to $2 \mathrm{~cm}$ long. This occurred at the first application date in 1984 (15 May) and 1985 (30 April) and the fourth date in 1986 (24 April) and third date in 1987 (7 May) (Fig. 1a, 2a, 3a, 4a). Applying mefluidide when $1 \%$ of the heads were visible 1 week later generally had little effect on reducing the number of floral stems. Applying mefluidide 1 week earlier in 1986 (Fig. 3a) and 1987 (Fig. 4a) when only a few of the floral primordium had been initiated also had little effect on reducing the number of floral stems. Length of time that floral primordium are initiated was similar to crested wheatgrass (White 1989) and much shorter than Caucasian bluestem [Bothriochloa caucasica (Trin.) C.E. Hubb.] (White 1990). Mefluidide was most effective in controlling heading of foxtail barley (Hordeum jubatum L.) (White 1984) and crested wheatgrass (White 1989) when applied 1 or 2 weeks after floral primor- 


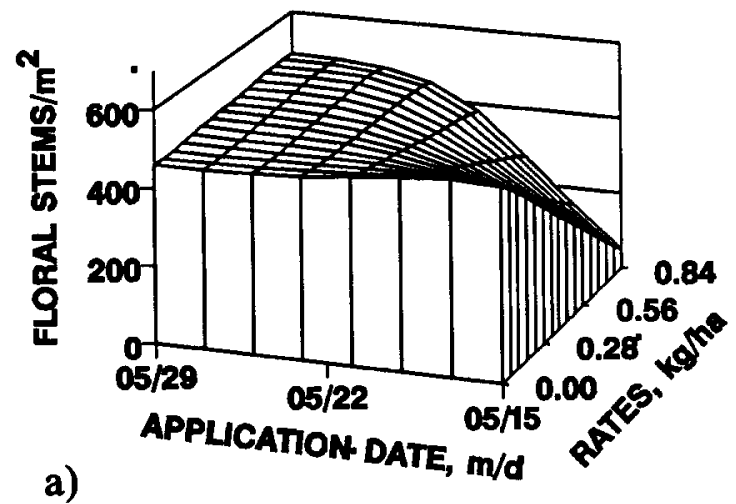

$R^{2}=0.81$, SE of mean $=0.9$

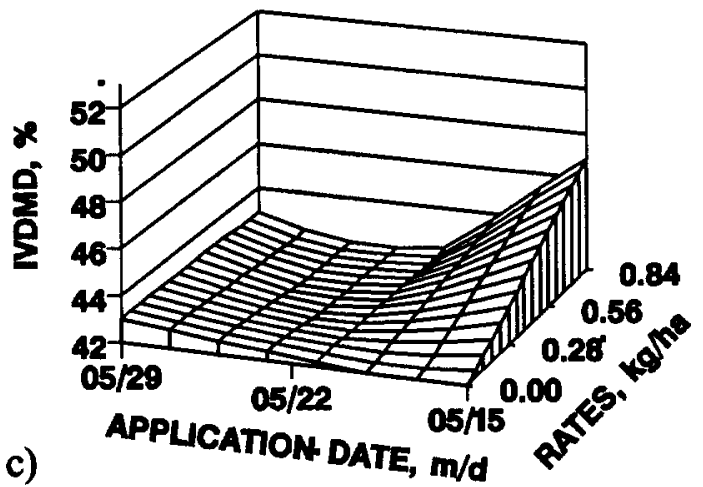

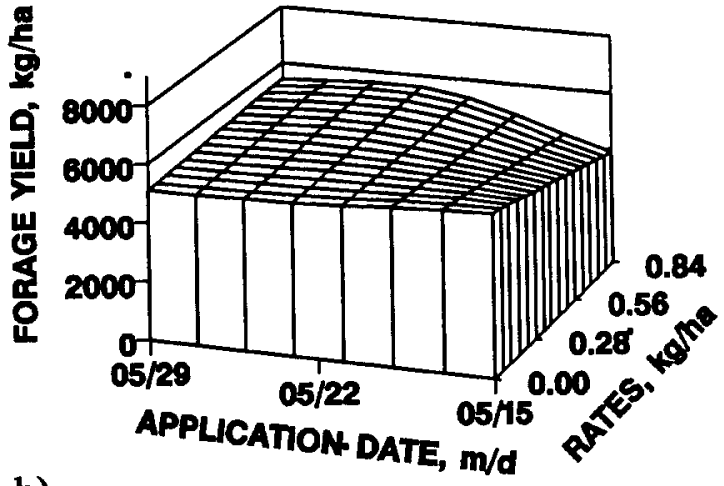

b)

$$
R^{2}=0.94, \text { SE of mean }=0.3
$$

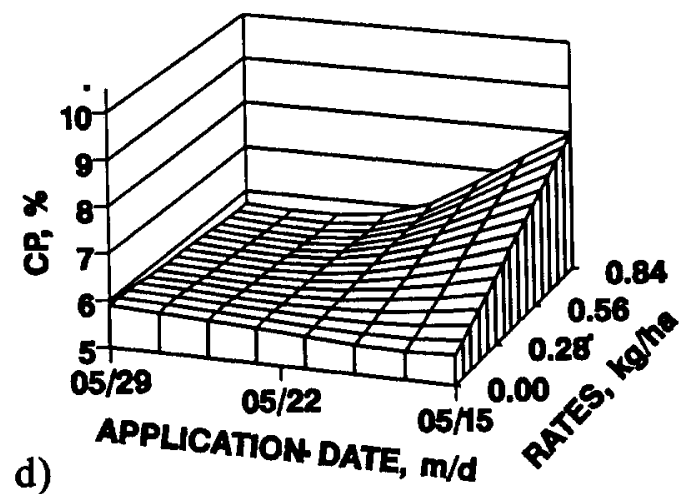

Fig. 1. Effects of 1984 mefluidide application dates and rates on floral stems (ä), forage yield (b), whole-plant IVDMD (c), and CP (d) of weeping lovegrass when harvested at the seed ripe near Woodward, Okla.

dium initiation. Van Esbroeck and Baron (1990) also found that application of mefluidide to smooth brome and meadow bromegrass (Bromus biebersteinii Roem and Schult.) was most effective when applied 0 to 1 week after most of the floral primordia were initiated. Others also have found that date of mefluidide application had a significant effect on controlling heading of perennial ryegrass (Lolium perenne L.) (Field and Whitford 1982), annual bluegrass (Poa annua var. reptans (Hauskins) Timm.] (Danneberger et al. 1987, Jagschitz 1985), and tall fescue (Gerrish and Dougherty 1983) but they did not correlate it with development of floral primordium.

Indices other than initiation of flora primordium can be used to determine when to apply mefluidide to lovegrass. These 4 years of data showed that mefluidide most effectively controlled floral stems of lovegrass if applied when $550 \pm 50$ degree days above $5^{\circ}$ $C$ had been accumulated since the 1st of February. In 1986 and 1987 the most effective time to apply mefluidide to lovegrass occurred when heads of 'Hawk' winter wheat (Triticum aestivum L.) was first fully visible above the crop canopy.

Of the lovegrass tillers heading in late May, $90 \%$ had started growth the previous fall [also reported by Field-Dogdson (1976) in South Africa] and had reached the 4 to 5th leaf stage (the prophyll was counted as the first leaf). Burnt leaves from early spring fire also could be used as further evidence of degree of leaf development at time of heading. Sampling in 1987 indicated that spring tiller initiation did not occur until mid-April, and few of those tillers developed heads that year. Lovegrass appeared to produce normally only 12 leaves (counting the prophyll as the first leaf) before the vegetative meristem differentiated into a floral primordium. Most floral primordium initiation of lovegrass occurred within a 2 week period.

Floral stems on control plots averaged 450 and $500 / \mathrm{m}^{2}$ in 1984 and 1985 but only 150 and 200 in 1986 and 1987 . My previous observations have shown that $\mathrm{N}$ fertilization of a thin stand of lovegrass caused many floral stems the first 2 years and as total number of tillers/unit area increased the number of floral tillers/unit area decreased. Kruger et al. (1976) also found that as the number of tillers/unit area increased the number of floral tillers/unit area decreased for lovegrass.

Application of increasing mefluidide rates $(0.00,0.28,0.56$, and $0.84 \mathrm{~kg} / \mathrm{ha}$ ) when floral primordia is 1 to $2 \mathrm{~cm}$ long resulted in a linear decrease in the number of floral stems in 1984 (Fig. 1a) and 1987 (Fig. 4a) and a quadratic decrease in 1985 (Fig. 2a) and 1986 (Fig. 3a). The $0.56 \mathrm{~kg} / \mathrm{ha}$ rate was chosen for discussion because of economic considerations and the quadratic response of floral stems 2 years out of 4 . Application of $0.56 \mathrm{~kg} / \mathrm{ha}$ of mefluidide would cost $\$ 34.57 / \mathrm{ha}$ and application of $0.84 \mathrm{~kg} / \mathrm{ha}$ would increase costs to $\$ 51.85 / \mathrm{ha}$. Application of $0.56 \mathrm{~kg} / \mathrm{ha}$ of mefluidide decreased number of floral stems $58,93,70$, and $58 \%$ in 1984 , 1985,1986 , and 1987 , respectively. It appears that mefluidide was 


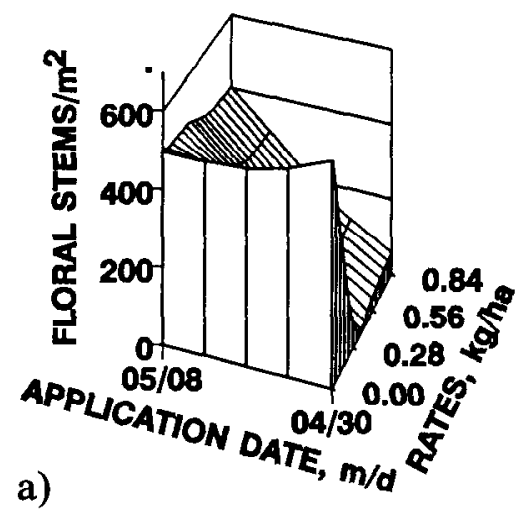

$R^{2}=0.87$, SE of mean $=0.7$

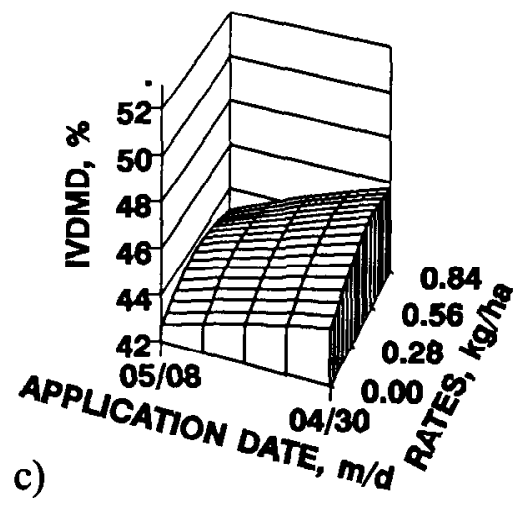

b)

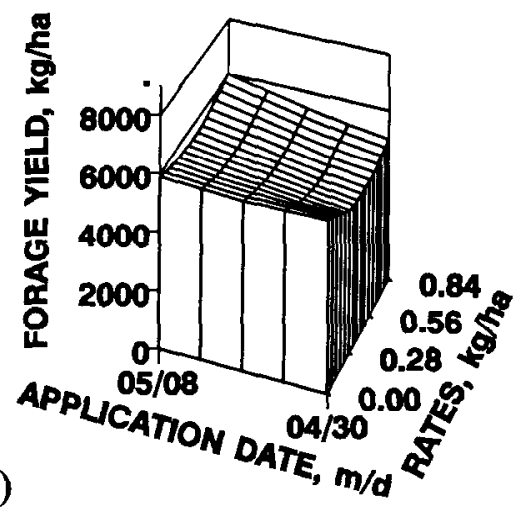

$$
R^{2}=0.81, \text { SE of } \operatorname{mean}=0.2
$$

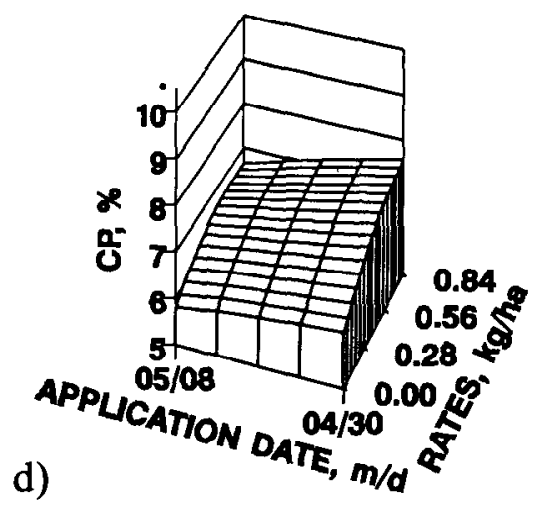

Fig. 2. Effects of 1985 mefluidide application dates and rates on floral stems (a), forage yield (b), whole-plant IVDMD (c), and CP (d) of weeping lovegrass when harvested at the seed ripe stage near Woodward, Okla.

more effective in reducing number of floral stems when 68 and 11 $\mathrm{mm}$ of precipitation was received 6 and 2 days after application in 1985 and 1986 than when only 2 and $5 \mathrm{~mm}$ was received 4 and 11 days later. More precipitation sooner after application should indicate higher relative humidity. McWhorter and Wills (1978) found that higher relative humidity after mefluidide application increased mefluidide's effectiveness. Field and Whitford (1982) also found that application of mefluidide during dry periods when soil water was limited was less effective in controlling heading. Mefluidide generally reduced the number of floral stems of lovegrass far less than the $90 \%$ reported for crested wheatgrass (Haferkamp et al. 1987, White 1989).

\section{Forage Yield}

Year, date, and rate of mefluidide application affected forage yield of lovegrass (Fig. 1b, 2b, 3b, 4b). Forage yield on control plots averaged $5,400,5,800,7,700$, and $3,200 \mathrm{~kg} / \mathrm{ha}$ in 1984,1985 , 1986, and 1987, respectively. Watering the site in late April 1986 resulted in increased forage yield that year. Application of less $\mathbf{N}$ in 1986 and 1987 may have caused the lower forage production in 1987 with fewer floral stems. Mefluidide reduced late June or early July forage yield most when applied about 1 week after floral primordium was initiated. Increasing rates of mefluidide 1 week after floral primordium initiation caused a linear decrease in forage yield in 1984, 1986, and 1987 but a quadratic decrease in 1985. Application of $0.56 \mathrm{~kg} /$ ha of mefluidide at this time decreased forage yield $20,14,23$, and $18 \%$ in 1984, 1985, 1986, and 1987 , respectively. Forage yield reduction by mefluidide was similar to that reported for crested wheatgrass (Haferkamp et al. 1987, White 1989, Van Esbroeck and Baron 1985), Caucasian bluestem (White 1990), and bermudagrass (Slade and Reynolds 1985), but less than that reported for smooth brome (Wimer et al. 1986).

\section{Leaf Yield}

Year, date, and rate of mefluidide application affected percent leaf yield. Percentage leaf yield of the total forage yield on control plots averaged 39, 41, 94 (Fig. 3c), and 62\% (Fig 4c) in 1984, 1985, 1986, and 1987, respectively. Watering the site in late April 1986 during a drought period may have increased percent leaf yield. Application of $0.56 \mathrm{~kg} / \mathrm{ha}$ of mefluidide 1 week after floral primordium initiation (15 May 1984, 30 April 1985, and 7 May 1987) increased percent leaf yield 20,32 , and 21 percentage units. But in 1986 with limited spring precipitation, application of $0.56 \mathrm{~kg} / \mathrm{ha}$ of mefluidide on 24 April only increased percent leaf yield by 4 percentage units compared to $95 \%$ leaf composition in the control. Increases in the proportion of leaves were inversely proportional to number of floral stems that mefluidide controlled.

Leaf yield on control plots averaged just over $2,000 \mathrm{~kg} / \mathrm{ha}$ in 
spline, SE of mean $=22$

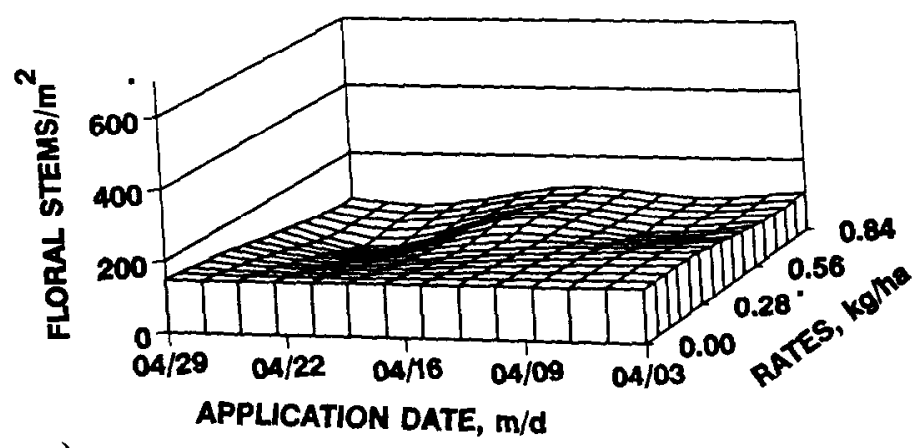

a)

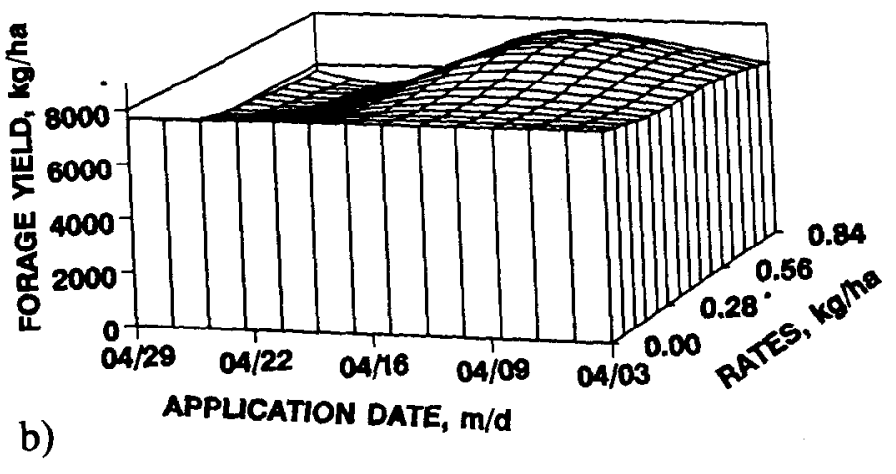

b)

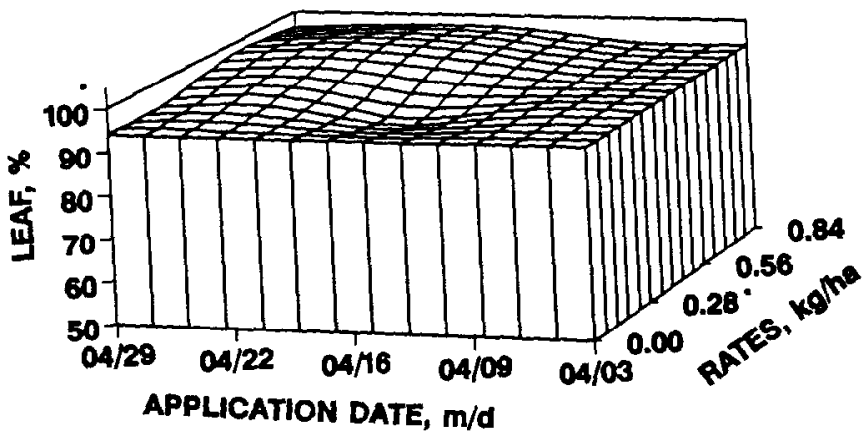

c) spline, SE of mean $=1$

spline, SE of mean $=0.5$

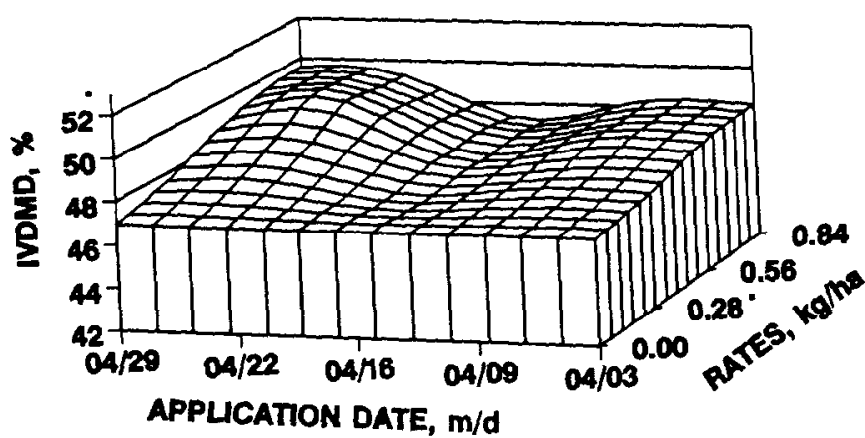

e)

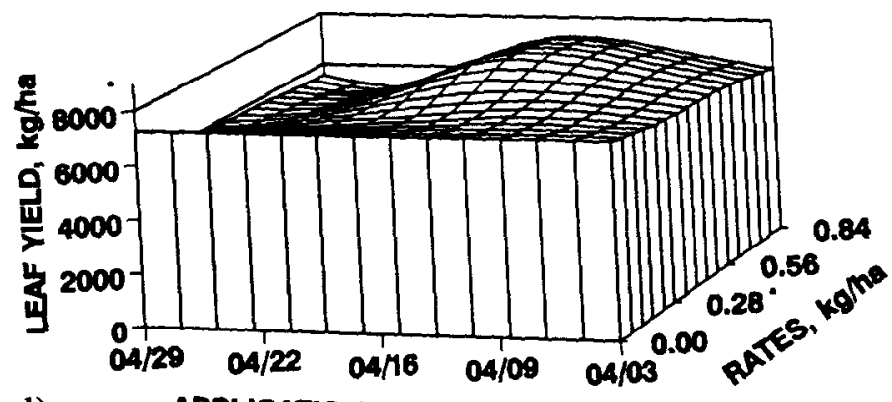

d) spllne, SE of mean $=285$

spline, SE of mean $=0.3$

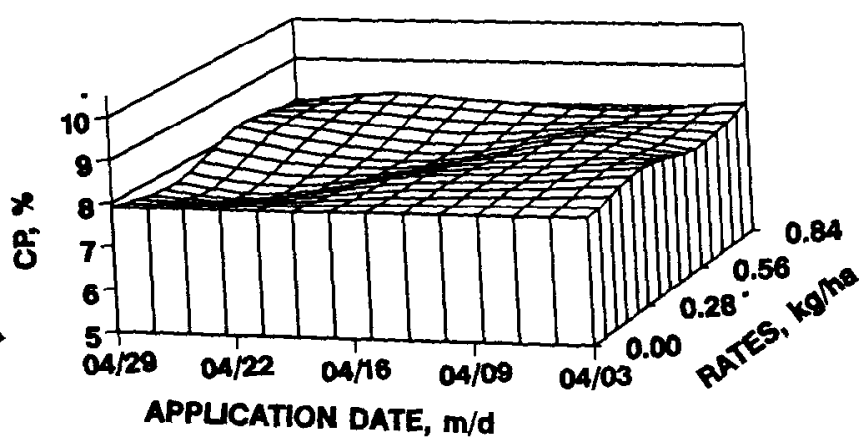

f) Fig. 3. Effects of 1986 mefluidide application dates and rates on floral stems (a), forage yield (b), perc
and CP (f) of weeping lovegrass when harvested at the seed ripe stage near Woodward, Okla. 


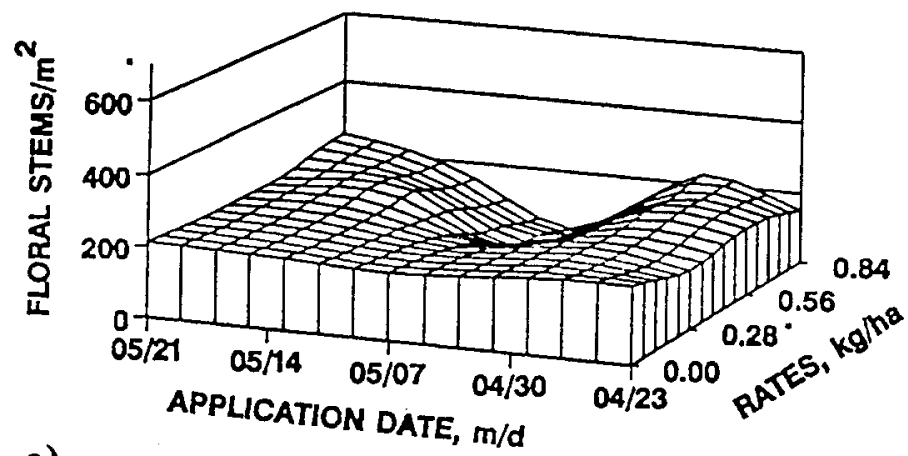

a)

spline , SE of mean $=3$

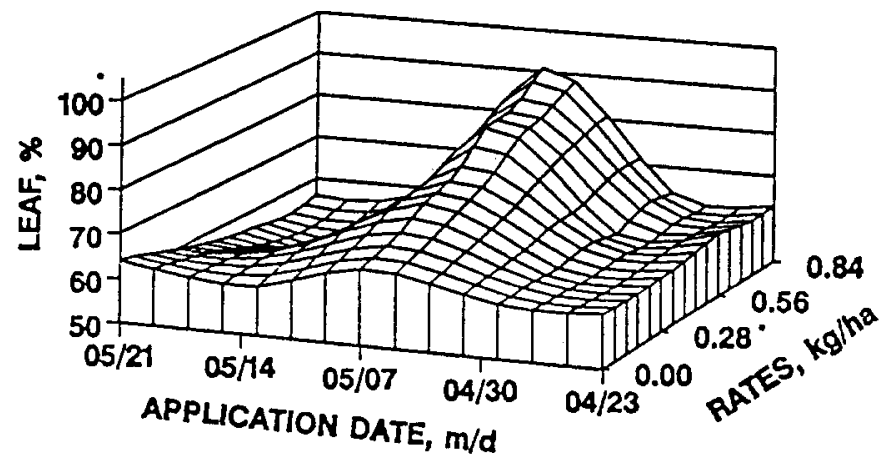

c)

spline, $\mathrm{SE}$ of mean $=0.6$

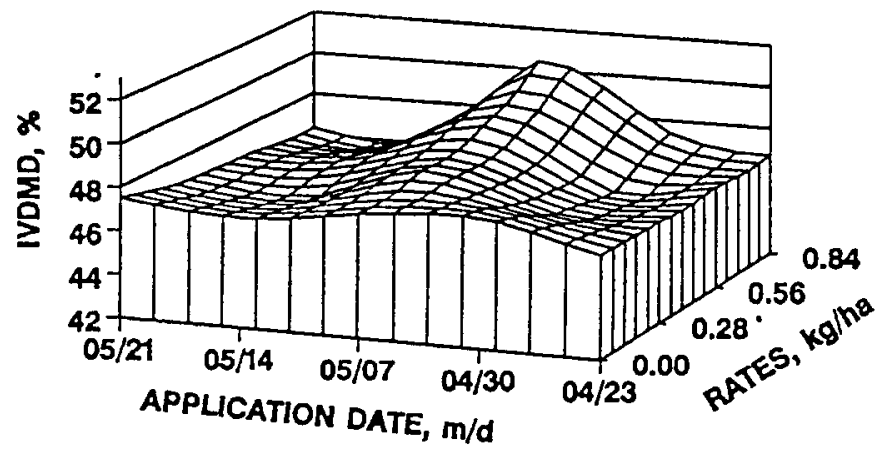

e)

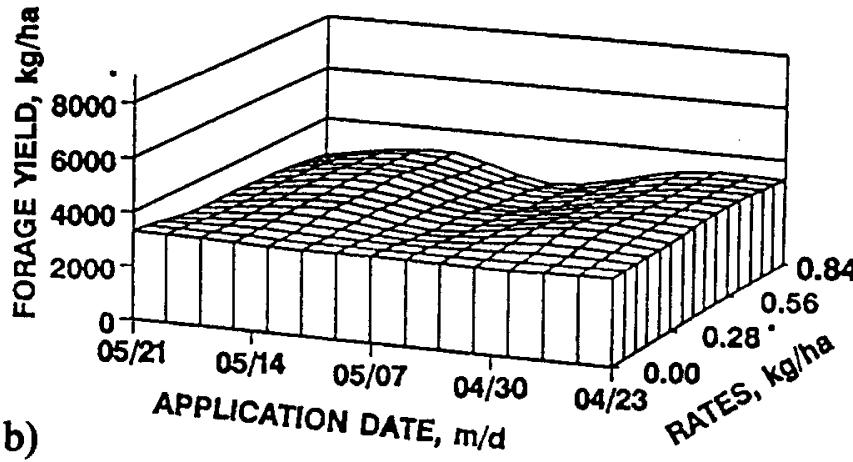

spline , SE of mean $=113$

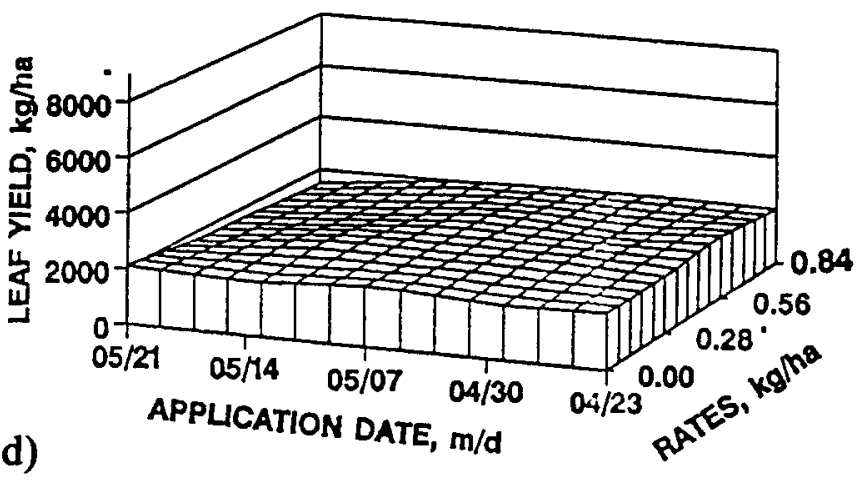

spline , SE of mean $=0.2$

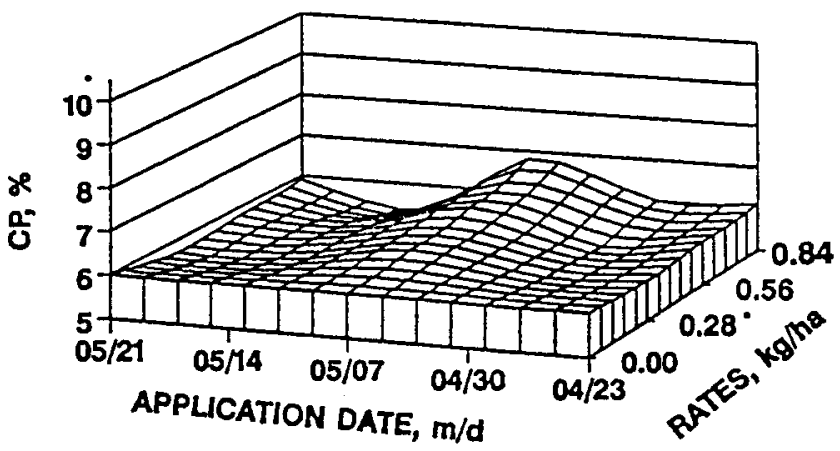

f)

Fig. 4. Effects of 1987 mefuidide application dates and rates on floral stems (a), forage yield (b), percent leaves (c), leaf yield (d), whole-plant IVDMD (e), and CP (f) of weeping lovegrass when harvested at the seed ripe stage near Woodward, Okla. 
1984,1985 , and 1987 but watering in 1986 increased leaf yields to over $7,000 \mathrm{~kg} / \mathrm{ha}$. Only in $1986 \mathrm{did}$ mefluidide application a week after floral primordium initiation decrease leaf yield (20\%). Mefluidide application to Caucasian bluestem in late May or early June reduced leaf yield 10 to $20 \%$ both years (White 1990). In contrast, Wimer et al. (1986) found that mefluidide application to smooth brome increased green leaf yield $64 \%$.

\section{IVDMD}

Year, date, and rate of mefluidide application affected wholeplant IVDMD (Fig. 1c, 2c, 3e, 4e) due to changes in leaf percentage but had no effect on leaf or stem IVDMD (Table 4). A decrease in

Table 4. The IVDMD and CP of leaves and stems of weeping lovegrass at seed ripe stage in 1984, 1985, 1986, and 1987 following mefluidide application one week after floral primordium initiation.

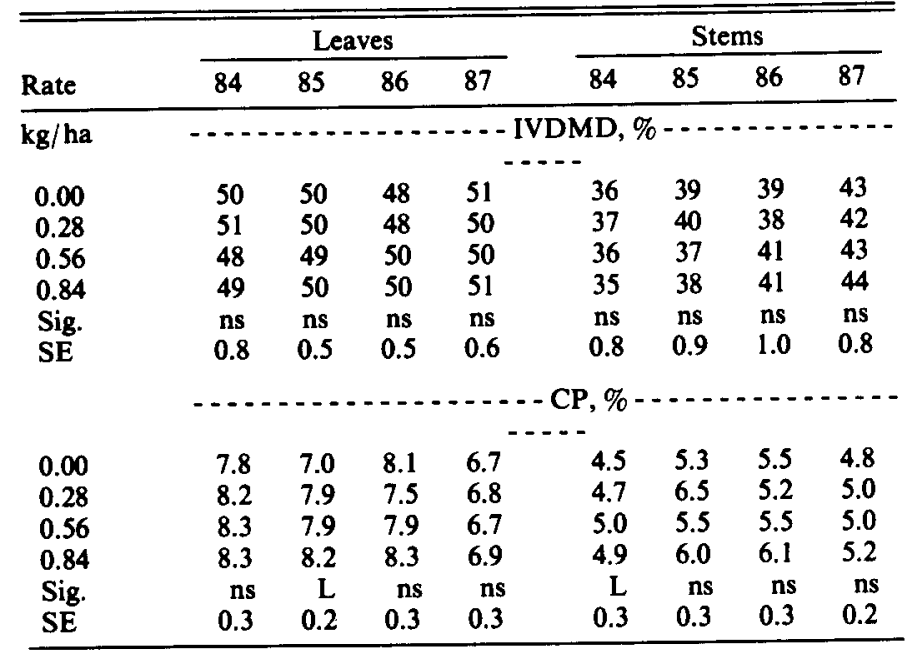

$\mathrm{SE}=$ standard error of mean, $\mathrm{L}=$ linear response, $P \leq 0.05$.

the number of floral stems on the control plots during the last 2 years increased whole-plant IVDMD by 3 to 4 percentage units. Application of $0.56 \mathrm{~kg} /$ ha of mefluidide 1 week after floral primordium initiation increased whole-plant IVDMD by 2.5, 2.8, 2.1, and 1.6 percentage units in $1984,1985,1986$, and 1987 , respectively. In 1985 increasing mefluidide rates caused a quadratic increase in whole-plant IVDMD but all other years it caused a linear increase. This increase was similar to the 2 to 5 percentage units that mefluidide increased whole-plant IVDMD of crested wheatgrass (Haferkamp et al. 1987, White 1989, Van Esbroeck and Baron 1985) and Caucasian bluestem (White 1990) but less than 10 percentage units that mefluidide increased IVDMD of smooth brome (Wimer et al. 1986). Leaf IVDMD on the control plots averaged 47 to $50 \%$ and stem IVDMD averaged 36 to $42 \%$ between 1984 and 1987 (Table 4). The 8 to 14 percentage units difference between leaf and stem IVDMD was greater than the 6 to 7 percentage units found for Caucasian bluestem (White 1990).

\section{Crude Protein}

Year, date, and rate of mefluidide application affected wholeplant CP (Fig. 1d, 2d, 3f, and 4f) of lovegrass all years while mefluidide rates had no effect on leaf or stem CP 3 of the 4 years (Table 4). The CP at seed ripe ranged from 6 to $8 \%$ for whole-plant, 7 to $8 \%$ for leaves, and 4.6 to $5.6 \%$ for stems on control plots (Table 4). Leaf CP of 7 to $8 \%$ would only be adequate for maintenance of mature cattle (NRC 1984). Whole plant and stem CP would be inadequate for all classes of cattle. Application of $0.56 \mathrm{~kg} / \mathrm{ha}$ of mefluidide to lovegrass 1 week after floral primordium initiation increased whole-plant CP $1.3,1.6,0.2$, and 0.5 percentage units in 1984, 1985, 1986, and 1987, respectively. This CP increase was similar to that reported for crested wheatgrass by Haferkamp et al.
(1987) and White (1989), but less than that reported by Van Esbroeck and Baron (1990). Application of increasing mefluidide rates to lovegrass caused a linear increase in whole-plant CP 3 years and a quadratic response in 1985 . Application of $0.56 \mathrm{~kg} / \mathrm{ha}$ of mefluidide to lovegrass increased leaf CP by 1.1 in 1985. Mefluidide had no effect on leaf or stem CP of lovegrass the other years.

\section{Conclusions}

Application of 0.56 or $0.84 \mathrm{~kg}$ / ha of mefluidide was effective in reducing lovegrass floral stems only when applied 1 week after floral primordium initiation. Application a week before or after had little effect. Because of economic considerations only the $\mathbf{0 . 5 6}$ $\mathrm{kg} /$ ha rate will be further considered. Application of $0.56 \mathrm{~kg} / \mathrm{ha}$ of mefluidide 1 week after floral primordium initiation reduced number of floral stems 58 to $93 \%$, which in turn reduced total forage yield 14 to $23 \%$ but had no effect on leaf yield or leaf quality. The effective 'window' for mefluidide application is probably too short for practical use by farmers or ranchers. However, mefluidide may be an effective tool for researchers to determine the effects of floral stem production on forage quality.

\section{Literature Cited}

Baron, V.S., G.A. Van Esbroeck, and A.C. Dick. 1989. Mefluidide effects on yield and quality of smooth bromegrass. Can. J. Plant Sci. 69:823-832.

Bremner, J.M., and G.A. Breitenbeck. 1983. A simple method for determination of ammonium in semimicro-Kjeldahl analysis of soils and plant materials using a block digester. Commun. in Soil Sci. Plant Anal. 14:905-913.

Cochran, W.G., and G.M. Cox. 1957. Factorial experiments, p. 148-182. In: Experimental designs. 2nd ed. John Wiley \& Sons, New York.

Danneberger, T.K., B.E. Branham, and J.M. Vargars, Jr. 1987. Mefluidide applications for annual bluegrass seedhead suppression based on degreeday accumulation. Agron. J. 79:69-71.

DeRamus, H.A., and C.P. Bagley. 1984. The effect of mefluidide treatment on bahia and bermudagrass and nutrient utilization, p. 152-156. In: Forage systems-leading U.S. agriculture into the future. Amer. Forage Grassl. Counc. 23-26 Jan. 1984, Houston, Texas.

Field, R.J., and A.R. Whitford. 1982. The retardation of grass growth by synthetic plant growth regulators, p. 485-504. In: J.S. McLaren (ed.). Chemical Manipulation of Crop Growth and Development. Butterworths, London.

Field-Dodgson, J. 1976. A study of seed production in Eragrostis curvula (Schrad.) Nees. Proc. Grassl. Soc. Southern Africa 11:109-114.

Gerrish, J.R., and C.T. Dougherty. 1983. Tall fescue sward response to mefluidide and nitrogen. Agron. J. 75:895-898.

Hacker, J.B., and D.J. Minson. 1981. The digestibility of plant parts. Herb. Abst. 51:459-482.

Haferkamp, M.R., R.F. Miller, and F.A. Sneva. 1987. Mefluidide effects on forage quality of crested wheatgrass. Agron. J. 79:637-641.

Jagschitz, J.A. 1985. Mefluidide timing for Poa annua L. seedhead suppression. Proc. N.E. Weed Sci. Soc. 39:268-269.

Kruger, J.A., I.B.J. Smit, and J.S. Swart. 1976. Dry matter production, tuft development and number of seed culms formed at different plant spacings of Eragrostis curvula (Schrad.) Nees. Agroplantae 8:1-6.

Laredo, M.A., and D.J. Minson. 1973. The voluntary intake, digestibility, and retention time by sheep of leaf and stem fractions of five grasses. Aust. J. Agr. Res. 24:875-888.

Lomas, L.W., and J.L. Moyer. 1985. Effect of treating tall fescue pasture with mefluidide on performance of grazing steers. J. Anim. Sci. 61(Suppl.1):342.

Minson, D.J. 1972. The digestibility and voluntary intake by sheep of six tropical grasses. Aust. J. Exp. Agr. Anim. Husb. 12:21-27.

McCaughey, W.P., and R.D.H. Cohen. 1989. Effect of plant growth regulators and harvest date on yield, botanical composition, chemical constitution, intake and digestibility of crested wheatgrass-alfalfa herbage by sheep. Can. J. Anim. Sci. 69:745-756.

MeWhorter, C.G., and G.D. Wills. 1978. Factors affecting the translocation of ${ }^{14} \mathrm{C}$-mefluidide in soybeans (Glycine max), common cocklebur (Xanthium pensylvanicum), and johnsongrass (Sorghum halepense). Weed Sci. 26:382-388. 
NRC. 1984. Nutrient requirements of domestic animals, No. 1. Nutrient requirements of beef cattle. 6th revised ed. Nat. Acad. Sci-Nat. Res. Counc. Washington, D.C.

Robb, T.W., D.G. Ely, C.E. Rieck, S. Glenn, L. Kitchen, B.P. Glenn, and R.J. Thomas. 1983. Beef production from fall fescue treated with mefluidide, a chemical plant-growth regulator, p. 725-728. In: J.A. Smith and V.W. Hays (eds.) Proc. XIV Int. Grassl. Congr., 15-24 June 1981, Lexington, $\mathrm{Ky}$.

Slade, J.J., and J.H. Reynolds. 1985. Plant growth regulator effects on forage quality of tall fescue and bermudagrass. Tennessee Farm and Home Sci. 134:19-23.

SAS Institute. 1988. SAS/GRAPH user's guide. SAS Institute Inc., Cary, N.C.

Sheaffer, C.C., and G.C. Marten. 1986. Effect of mefluidide on cool-season perennial grass forage yield and quality. Agron. J. 78:75-79.

Twidwell, E.K., K.D. Johnson, J.H. Cherney, and J.J. Volenec. 1988. Forage quality and digestion kinetics of switchgrass herbage and morphological components. Crop Sci. 28:778-782.
Van Esbroeck, G.A., and V.S. Baron. 1990. Effect of mefluidide application date on yield and forage quality of Bromus species. Can. J. Plant Sci. 70:717-726.

Voigt, P.W., F.P. Horn, and C.L. Dewald. 1981. Forage quality response of four lovegrasses to stage, interval, and season of harvest. Agron. J. 73:877-884.

White, L.M. 1984. Foxtail barley heading, yield and quality as influenced by growth regulators and a desiccant. Agron. J. 76:27-30.

White, L.M. 1989. Growth regulators' effect on crested wheatgrass forage yield and quality. J. Range Manage. 42:46-50.

White, L.M. 1990. Mefluidide effect on Caucasian bluestem leaves, stems, forage yield, and quality. J. Range Manage. 43:190-194.

White, L.M., G.P. Hartman, and J.W. Bergman. 1981. In vitro digestibility, crude protein, phosphorus content of straw of winter wheat, spring wheat, barley, and oat cultivars in eastern Montana. Agron. J. 73:117-121.

Wimer, S.K., J.K. Ward, B.E. Anderson, and S.S. Waller. 1986. Mefluidide effects on smooth brome composition and grazing cow-calf performance. J. Anim. Sci. 63:1054-1062. 